\title{
Determinants of Climate Change Adaptation Strategies Among Farm Households in Delta State, Nigeria
}

\author{
Enimu Solomon* and Onome George Edet \\ Department of Agricultural Economics, Nigeria
}

Received: November 14, 2018; Published: 啙 November 21, 2018

*Corresponding author: Enimu Solomon, Department of Agricultural Economics, Nigeria

\begin{abstract}
The study examined the determinants of climate change adaptation strategies among farm households in Delta State, Nigeria. A total of 1200 farm households were randomly selected through multi-stage random sampling techniques. The study data was collected by questionnaire. Statistical tools such as simple descriptive statistics (table, frequency, percentage and mean) and a binary logistic regression model were used to examine the data. The results indicate that $43 \%$ of the respondents were crop producers while $31 \%$ were livestock producers. Majority of the farmers $100 \%$ and $99 \%$ adopted adjustment of farming operation time and increase use of agricultural inputs as their major adaptation measures respectively. The result of the binary logistic regression model demonstrated that the determinants of the likelihood of adopting adaptation strategies by farmers included the households' heads age, gender, educational level, farming experience, access to credit, farm/herd size, membership of cooperative, household income, and access to weather information and access to extension services. Therefore, it was recommended that the determinants that influence farmer's likelihood of adopting adaptation measures positively should be carefully examine, harnessed and properly utilized for sustainable rural and agricultural development.
\end{abstract}

Keywords: Determinants; Climate Change; Adaptation; Strategies; Households

\section{Introduction}

Climate is generally conceived as the expected weather conditions for specific geographical location. Climate change is defined as any long-term change in the statistics of weather over duration ranging from decades to millions of years [1]. It can be manifest in changes to averages, extremes, or other statistical measures, and may occur in a specific region or for the earth as a whole. Okali and Eleri [2] stated that climate change is the synthesis of the weather in a given location over a period of at least 30 years. The intergovernmental panel on climate [3] defined vulnerability as the degree to which a system is susceptible to, or unable to cope with the adverse effects of climate change, including climate variability and extremes and adaptation as, adjustments in ecological, social or economic system in response to actual or expected stimuli and their effects or impact. Climate change is a major threat to sustainable growth and development in Africa, and more especially in Nigeria. The evidence that climate change will adversely affect agriculture in Nigeria has become a crucial challenge. This challenge is composed of the likely impacts on ecosystem services, agricultural production, and livelihood [4].

Generally, losses in the agricultural sector due to climate change has economy wide consequences, like loss in gross domestic output, a decline in the income/consumption of the most vulnerable population; hence, a general deterioration in households' welfare. The causes of climate change are both natural and anthropogenic as conceptualized. The on-going climate change and its associated global warming are expected to cause distinctive climate pattern in different climate zones, which will impact negatively on the ecosystem [5]. The major global environmental changes significantly affecting mankind according to Ikeme (2009) include climate change and ozone depletion. It is a protective shield to life on earth, preventing much of the sun's ultraviolet (UV) radiation; especially UV radiation with shorter wavelength from reaching the earth. To dampen the adverse consequences of climate change, there is a need for farmers to adopt different adaptation strategies. 
Adaptation to the adverse consequences of climate change could be viewed from tow perspectives,

a) The awareness of the risks of climate change and their capacity to adapt to climate change.

b) How adaptation can be carefully planned and implemented to avoid the possibility of mal-adaptation (Food and Agricultural Organization (FAO), [6]. While the formal can be enhanced by providing relevant information to the vulnerable population about the risk and consequences of climate change, the later involves technical developments and government insurance, which are principally the responsibility of public agents, agribusiness and government [6].

The efforts made by the small-scale farmers to adapt with the changing climate at local level are mostly unorganized and influenced by a set of factors. It needs well integrated and holistic approach to the entire system of the agriculture sector to make sensitive climate change impact as climate change often appears very esoteric but in Nigeria generally and Delta State of Nigeria in particular, it is real and this calls for critical study like this, in which the researcher would highlight the perception, effects, and adaptation strategies used, problems and proffer possible solutions to mitigate its devastating effects on our populace and environment.

\section{Objective of the Study:}

The broad objective of the study is to evaluate the determinants of climate change adaptation strategies among farm households in Delta State, Nigeria. The specific objectives are to:

a) Identify the major livelihood choices of the respondents.

b) Examine various adaptation strategies used by the farmers, and

c) Determine factors that affect farmer's adaptation to climate change.

\section{Hypothesis for the Study}

The study is guided by the following null hypothesis:

a) No significant relationship exists between the captured factors and farmers adaptation strategies to climate change.

\section{Materials and Methods}

\section{Study Area}

The study was conducted in Delta State, of Nigeria created on August 27, 1991 out of the defunct Bendel State. The Global Position System (GPS) coordinates are between $5^{0} 30^{1} \mathrm{~N} 6^{0} 00^{1} \mathrm{E}$ and $5^{0} 30^{1} \mathrm{~N}$ $6^{0} 45^{1} \mathrm{E}$. The land area is $17,011 \mathrm{~km}^{2}(6,833$ sq. $\mathrm{m})$, area rank $23^{\text {rd }}$ out of 36 states. According to the National population commission (2006), Delta State has a population of 4,098,391 which is made up of 2,074,306 males and 2,024,085 females ranked $9^{\text {th }}$ out of 36 states. Delta State is one of the highest producers of crude petroleum products in the country with anticipated exploration, exploitation and regular gas flare. However, as with most parts of the country, agriculture is the dominant aspect of the rural economy of the state. Agriculturally, the state is divided into three zones, namely, North, Central and the South zones. Generally, the major food crops grown include yam, cassava, maize, cocoyam and rice with cash crops like rubber, oil palm, cocoa, mango, timber and assorted vegetables. Livestock produced include small ruminants, poultry, pigs, rabbits, grass cutter, snails and bee farming. Cultured and captured fisheries are also prominent in the state besides forest and wildlife production.

\section{Data Source}

This study was both primary and secondary data. Primary data were obtained using structured questionnaire and interview schedule. The data focused on socio economic characteristics, adaptation strategies used, and problem faced by small scale farmers. Climate variables including mean temperature, and precipitation level within a period of one year. Climate data were obtained from the Nigeria Meteorological Agency (NIMET) database.

\section{Sampling Procedure and Data Analysis}

A multi-stage sampling technique was employed in the study. First, Four Local Government Areas (LGAs) most prone to climate variability were purposively selected from each of the three agricultural zones respectively, giving a total of twelve (12) LGAs. The second stage involves the random selection of Ten (10) communities each from the LGAs using the proportionate sampling method; this gave a total of one hundred and twenty (120) communities. In the last stage, ten (10) farm households were then randomly selected from each of the 120 communities giving a total of one thousand, two hundred (1200) respondents for the study. Descriptive statistics, such as mean, percentage, frequency distribution and binary logit model were used to realize the objectives.

\section{Model Specification}

The binary logit model was used because its underlying assumptions are less restrictive than those of other methods and is free from problems attendant with the use of ordinary least square [7]. The observation on the dependent variable (Y) of this model is dichotomous that is, having a binary value of one (1) if the farmers adapt to climate change using various strategies and zero $(0)$ if otherwise. In the logit model, it is assumed that the use of adaptation strategies is a long-linear function of the exogenous variables $\mathrm{X}_{1}, \mathrm{X}_{2}$ of the term.

$$
L_{i}=\operatorname{In} \frac{P_{i}}{1-P_{i}}=Z_{i}=B_{0}+B_{1} X_{1}+B_{2} X_{2}+\ldots \ldots . . B_{n} X_{n}
$$


That is $\mathrm{L}$; the log of the odds ratio is not only linear in $\mathrm{X}_{\mathrm{i}}$ but also linear in the parameters.

Where:

$\mathrm{L}=$ Logit model.

$\mathrm{P}=$ is the probability of using adaptation strategies. Denote as,

$$
P=\frac{1}{1+e^{-2}}=\frac{e^{z}}{1+e^{z}}
$$

Where

$$
Z=B_{0}+B_{1} X_{1}+B_{2} X_{2}+\ldots \ldots B_{n} X_{n}
$$

For estimation purpose, we write the explicit form as follows:

$$
L_{i}=\left(\frac{P}{1-P_{i}}\right)=Z_{i}=b_{0}+b_{1} x_{1}+b_{2} x_{2}+b_{3} x_{3}+b_{4} x_{4}+b_{5} x_{5}+b_{6} x_{6}+b_{7} x_{7}+b_{8} x_{8}+b_{9} x_{9}+b_{10} x_{10}+b_{11} x_{11}+b_{12} x_{12}+b_{13} x_{13}+u d
$$

Where:

$\mathrm{Y}=$ Dependent variable (measured in binary term)

$\mathrm{B}_{1}-\mathrm{b}_{13}=$ Coefficient of independent variables.

$\mathrm{b}_{0}=$ Intercept

$\mathrm{X}_{1}=$ Age of household head (in years)

$\mathrm{X}_{2}=$ Gender of household head (if male $=1,0$ if female)

$\mathrm{X}_{3}=$ Marital Status (Married 1, otherwise 0)

$\mathrm{X}_{4}=$ Household size (number of individual)

$\mathrm{X}_{5}=$ Education of household head (years)

$\mathrm{X}_{6}=$ Farming Experience (in years)

$\mathrm{X}_{7}=$ Access to credit (Access $=1,0$ Otherwise)

$\mathrm{X}_{8}=$ Household income (in Naira)

$\mathrm{X}_{9}=$ Farm/herd size (in hectare/number)

$\mathrm{X}_{10}=$ Membership of cooperative (if any 1, 0 otherwise)

$\mathrm{X}_{11}=$ Household income (in Naira)

$\mathrm{X}_{12}=$ Access to wealthier information $(1=$ yes, $0=$ no $)$

$\mathrm{X}_{13}=$ Access to Extension Service $(1=$ yes, $0=$ no $)$

$\mathrm{Ut}=$ Error term.

\section{Results and Discussion}

\section{Major Occupation/Livelihood Choice of Respondents}

According to Gebru and Beyene [8], people make livelihood choices based on the level of their household assets or availability of infrastructure in their community. Table 1 shows the frequency
Therefore, the probability of not using adaptation strategies is:

$$
1-P=\frac{1}{1+e^{-2}} \frac{P}{1-P}=\frac{1+e^{-2}}{1+e^{-2}}
$$

Now, $\mathrm{P} /(1-\mathrm{P})$ is simply the odds ratio in favour of using adaptation strategies, that is, the ratio of the probability that the farmer will use adaptation strategies to cushion the effect of climate change to the probability that he will not.

Thus, if $\mathrm{P}=0.9$, it means that odds are 0 to 1 in favour of using adaptation strategies. Therefore, if $\mathrm{P}$ goes from 0 to 1 (that is, as $\mathrm{Z}$ varies from $-\mathrm{X}_{\mathrm{i}}$ to $+\mathrm{X}_{\mathrm{i}}$ ) the logit, $\mathrm{L}$ goes from $-\mathrm{X}$ to $+\mathrm{X}$. That is, although the probability lies between 0 and 1 , the logit is not so bounded. 
the major occupation and source of livelihood respectively. These findings conform to work by Olawuyi and Rahji [9], Ekong [10] and Adepoju and Obayelu [11], which stated that most rural households in Nigeria engage in multiple livelihood activities such as trading, small scale business enterprises and processing of agricultural goods and arts and craft in order to supplement earning from farming.

Table 1: Distribution of Respondents Based on Major Occupation.

\begin{tabular}{|c|c|c|}
\hline Livelihood Choices & Frequency (N = 1,200) & Percentage \\
\hline Crop Production & 510 & 42.5 \\
\hline Livestock Production & 370 & 30.8 \\
\hline Fisher Folks & 215 & 17.9 \\
\hline Agric Business Owner & 105 & 8.8 \\
\hline Total & 1,200 & 100 \\
\hline
\end{tabular}

\section{Adaptation Strategies Used by Respondents}

It is evident that the farmers are aware of climate change in their locality and in response of the risks on agricultural productivity had adopted various adaptation strategies. Table 2 shows the various adaptation strategies adopted by farmers in the study area. The table revealed that $100 \%$ of the respondent adjusted their operation time to favour higher productivity and returns, while 98.5\% increase their use of agricultural inputs. However, $81.8 \%$ of the farmers increase size of land and fishing time, while $71.8 \%$ make adjustment in price of their products. More so, 68.8\%, 53.3\%, $52.5 \%, 42.3 \%$ and $17.9 \%$ of the respondent adopted temporary migration to new sites, intensification of irrigation, use of resistant varieties, crop diversification and fodder tree planting respectively. Only $1.5 \%$ of the respondents do not use adaptation strategy. The multiple responses recorded indicated that majority of the farmers who implemented adaptation measures have a propensity of implementing multiple adaptation strategies in combination. The result conforms to work by Nhemachena [12].

Table 2: Adaptation Strategies Adopted by Farmers.

\begin{tabular}{|c|c|c|c|c|}
\hline S.No & $\begin{array}{l}\text { Adaptation } \\
\text { Strategies }\end{array}$ & Frequency & Percentage & Rank \\
\hline 1 & $\begin{array}{l}\text { Intensification of } \\
\text { Irrigation }\end{array}$ & 640 & 53.3 & $6^{\text {th }}$ \\
\hline 2 & $\begin{array}{c}\text { Increase use of } \\
\text { Agricultural Inputs }\end{array}$ & 1182 & 98.5 & $2^{\text {nd }}$ \\
\hline 3 & $\begin{array}{l}\text { Adjustment in } \\
\text { Operation Time }\end{array}$ & 1200 & 100 & $1^{\text {st }}$ \\
\hline 4 & Crop diversification & 507 & 42.3 & $8^{\text {th }}$ \\
\hline 5 & $\begin{array}{l}\text { Increasing size of } \\
\text { land/fishing time }\end{array}$ & 982 & 81.8 & $3^{\text {rd }}$ \\
\hline 6 & Fodder tree planting & 215 & 17.9 & $9^{\text {th }}$ \\
\hline 7 & $\begin{array}{l}\text { Temporary } \\
\text { migration to new } \\
\text { sites }\end{array}$ & 826 & 68.8 & $5^{\text {th }}$ \\
\hline
\end{tabular}

\begin{tabular}{|c|c|c|c|c|}
\hline 8 & $\begin{array}{c}\text { Use of resistant } \\
\text { varieties }\end{array}$ & 630 & 52.5 & $7^{\text {th }}$ \\
\hline 9 & $\begin{array}{c}\text { Adjustment of } \\
\text { prices }\end{array}$ & 856 & 71.8 & $4^{\text {th }}$ \\
\hline 10 & No adaptation & 18 & 1.5 & $10^{\text {th }}$ \\
\hline & Total & $1200^{*}$ & 100 & \\
\hline
\end{tabular}

Factors Influencing Farmers' Adaptation to Climate Change

Table 3: Estimates of the Logistic Regression Model for Factors Influencing Farmers.

\begin{tabular}{|c|c|c|c|c|}
\hline \multicolumn{5}{|c}{ Adaptation to Climate Change } \\
\hline Variables & Coefficients & P-Value & Exponential & StdError \\
\hline Age & $-0.3394^{*}$ & 0.085 & 1.352 & 2.334 \\
\hline Gender & $0.0342^{* *}$ & 0.037 & 0.371 & 0.002 \\
\hline Marital Status & 2.4283 & 0.348 & 0.413 & 0.913 \\
\hline Household Size & 0.2358 & 1.532 & 1.832 & 0.003 \\
\hline $\begin{array}{c}\text { Educational } \\
\text { Level }\end{array}$ & $0.1927^{* * *}$ & 0.003 & 1.001 & 0.141 \\
\hline $\begin{array}{c}\text { Farming } \\
\text { Experience }\end{array}$ & $1.2417^{* * *}$ & 0.001 & 0.053 & 1.33 \\
\hline Access to Credit & $0.2361^{*}$ & 0.078 & 0.821 & 0.149 \\
\hline Farm/Herd Size & $-0.0057^{*}$ & 0.056 & 0.337 & 0.015 \\
\hline $\begin{array}{c}\text { Membership of } \\
\text { Cooperative }\end{array}$ & $0.3019^{* *}$ & 0.041 & 0.348 & 1.875 \\
\hline $\begin{array}{c}\text { Household } \\
\text { Income }\end{array}$ & $0.8314^{* *}$ & 0.057 & 0.331 & 0.015 \\
\hline $\begin{array}{c}\text { Access to } \\
\text { Weather } \\
\text { Information }\end{array}$ & $0.2151^{* * *}$ & 0.002 & 0.413 & 0.087 \\
\hline $\begin{array}{c}\text { Access to } \\
\text { Extension } \\
\text { Services }\end{array}$ & $0.4418^{*}$ & 0.05 & 0.923 & 0.132 \\
\hline \begin{tabular}{c} 
Constant \\
\hline Bonat
\end{tabular} & $-8.4143^{* * *}$ & 0.004 & 1.731 & 5.392 \\
\hline
\end{tabular}

Binary logistic regression model was used to identify variables that influence small scale farmers in adapting to climate change effects, that is, the probability that a farmer will adapt strategies to climate change in a bid to mitigating its effects. The regression classification table indicated that the binary logistic model predicted about $92.73 \%$ of the responses correctly. The model fits the data at $(\mathrm{p}<0.001)$ as indicated by the chi-square goodness of fit statistic (83.94). the goodness of fit demonstrated that the variables captured in this study were valid to explain the factors that determine the willingness of a farmer to adopt any adaptation strategy in tackling climate change in the study area. Besides, the Nagelkerte $R^{2}$ value $(0.918)$ shows that about $92 \%$ of the outcome (Likelihood of adapting an adaptation strategy) can be explained by the selected independent variables captured in the model. 
Therefore, we reject the null hypothesis and accept the alternative hypothesis stating a significant relationship between the captured variables and farmer's willingness to adopt adaptation strategy to climate change. Age, gender educational level, farming experience, access to credit, farm/herd size, membership of cooperative, household income, access to weather information and access to extension services appeared to have significant effect on adaptation of multiple strategies to combat climate change (Table 3).

Percentage prediction $=92.73 \%$, Goodness of fit chi-square $(\mathrm{df}=11)=83.94 \%(\mathrm{P}<0.001)$, Negelkerte $\mathrm{R}^{2}=0.918 .{ }^{*}, * *$, and ${ }^{* * *}$ represent significant at $\mathrm{P}<0.01, \mathrm{P}<0.05$ and $\mathrm{P}<0.1$ respectively. The coefficient of age of household head was negative and significant at $10 \%$ level. This implies that as the household head age increases his/her willingness to adopt adaptation strategies decreases. The result contrasts work by Deressa [13] which pointed out a positive association of age with adaptation to climate changes.

The coefficient for gender was significant at $1 \%$ and positively related to adaptation to climate change. This indicated that as you move from 1 (male) to zero (0) (female), more male household head had better probability to take an adaptation measure than their female household heads. This conforms to a priori expectations and parallels the work of Deressa [13], Asfaw and Assefa [14] which argued in favour of these findings that male headed households are often considered to be more likely to get information about new technologies and take on risk than female headed households. In contrast, Nhemachena and Hassan [15] stated that female headed households are more likely to take up climate change adaptation methods. Education which implies the number of years spent schooling, also conformed to $a$ priori expectations with a positive coefficient, and is significant at $1 \%$. This means that the higher the educational level of the head of household, the higher the likelihood of adapting to climate change. The result confirms a strong relationship between educational status of household head and the probability of adopting adaptation measures. The result supports the findings of Dressa [13]. The coefficient of farming experience was significant at $1 \%$ level and positively related to adopting adaptation measures, which indicates that the higher the years of farming experience, the higher the likelihood of adopting adaptation measures. This parallels a priori expectations and conforms to Gbetibouo [16] results, which reveals that farming experience positively relates to the probability of adopting adaptation measures.

Access to credit had a positive coefficient, and is significant at $10 \%$ level, suggesting an increase in adopting adaptation measures as farmers access more credit. The advantage of credit provision in solving the financial constraints of farmers to invest on agricultural technologies was clearly expressed in the result. This conforms to a priori expectations and also agrees with results from Gbetibouo [16] and Nhemachena [15] which reported that access to credit increases the likelihood that farmers will take up portfolio diversification and buy feed supplements for their livestock.

Farm/herd size had a negative coefficient, and is significant at $10 \%$ level, implying a decrease in adopting adaptation measures as the farm/herd size increases. Farmers with large farm/herd sizes had lower likelihood of adopting adaptation measures in reducing the negative impact of climate change. As opposed to these findings Gbetibouo [16] reported a positive significant coefficient between farm size and the likelihood of adapting to climate change while Tesfaye [17] reported that number of livestock owned had a significant and positive influence on the adoption of fertilizer. But contrast Dressa [13]. The coefficient of membership of cooperative was significant at 5\% level and positively related to adopting adaptation measures. This implies that belonging to a cooperative increases the likelihood of adopting adaptation measures. This result is in conformity to a priori expectations and works by Maddison [18] who stated that being a member of an association help to sensitive the farmers on ways of adapting to effects of climate change. Household income had a positive coefficient and significant at $5 \%$ level, demonstrating that the higher the household income, the higher the likelihood of adopting adaptation measures. This conforms to a priori expectations and work by Dressa [13] which reported a positive relationship between farm income and adoption of soil conservation practices, use of different crop varieties and adjustment in planting date in combating climate change effects.

Access to weather information appear to have a positive coefficient and was significant at $1 \%$ level on its influence on the decision of performing adaptation measures in response of climate change problem. This implies that farmers with better access to information of the changing climate have more probability of adopting adaptation measures. This conforms to a priori expectations and work by Maddison [18], Nhemachena and Hassan [15] which reported that information on rainfall and temperature had s significant and positive impact on the likelihood of using different crop varieties by $17.6 \%$. The coefficient of access to extension services was significant at $10 \%$ level and positively related to adopting adaptation measures. This indicates that the more access to extension services, the higher the likelihood of the farmers to adopt adaptation measures. The result conforms to a priori expectations which depict a positive relationship between access to extension services and adoption of adaptation measures as farmers will be more aware of the problem of climate change. This result also conforms to work by Nemachena [12], Gbetibouo [16] and Apata [4].

\section{Conclusion}

Conclusively, measures are continuously being adopted to mitigate the ravaging effect of climate change on agricultural productivity, growth and sustainable development. Majority of the rural small scale farmers are aware of the consequences of climate 
change on their livelihood and the environment at large. Based on the result of the binary logistic regression model, it was revealed that, gender, educational level, farming experience, access to credit, membership of cooperative, household income [19-21], access to weather information and access to extension services had a positive and significant relationship with the likelihood of farmers to adopt adaptation measures while age of household head and farm/herd size had a negative and significant relationship on the probability of farmers to adopt adaptation measures. From the foregoing therefore, it was recommended that:

a) The determinants which influence farmer's likelihood of adopting adaptation measures should be harnessed and properly utilized.

b) Weather institute should create more awareness on the devastating effects of climate change.

c) Incentives should be made readily available to cushion the menace of climate change.

d) Farmers should diversify the choices of livelihood as this will serve as co-insurance.

e) Extension officers should work harder and brace up to the challenge of climate change.

f) Financial institutions should make credit available to farmers for easy farming operations and adjustment.

\section{References}

1. Ekweozoh PC and GN Njoku (2010) Technology Transfer Issues in Climate Change: Challenge and Prospects for Africa. Proceedings of the Second Science with Africa Conference. Federal Ministry of Science and Technology, Abuja, Nigeria.

2. Okali D and Eleri EO (2004) climate change and Nigeria: A guide for policy makers, Abuja, Nigeria Environmental Study Action Team (NEST) Publication.

3. IPCC (2001) Climate change 2001: Impacts, Adaptation and Vulnerability. In: JJ Mc Carthy, OF Canziani, NA Leary, DJ Dokken, and KS White (Eds.), IPCC Working Group II, Third Assessment Report, Cambridge University Press, USA.

4. Apata TG (2011) Factors influencing the perception and choice of adaptation measures to climate change among farmers in Nigeria: Evidence from farm households in Southwestern Nigeria. Environ Econ 2(4): 74-83.
5. Mshelia AD (2005) Adaptation Strategies to Climate Change Energy and Environment 8(3): 61-68.

6. FAO (2007) Adaptation to climate change in agriculture, forestry, and fisheries: Perspective, framework and priorities, FAO. Rome, USA.

7. Gajurati ND (2004) Basic Econometrics. (4th eds). New York, USA Tata McGraw Hill Company Inc.

8. Gebru GW and F Beyene (2012) Rural household livelihood strategies in drought - prone areas: A case of Gulomekeda District, Eastern Zone of Tigray National Regional State, Ethiopia. J Dev Agric Econ 4(6): 158-168.

9. Olawuyi SO and MAY Rahji (2012) Analysis of Livelihood Strategies of household's head in Ode-Oni Kingdom, Ogun-Waterside Local Government Area, Ogun State, Nigeria. IJRRAS II (2): 338-345.

10. Ekong EE (2003) Rural Sociology: An introduction and analysis of rural Nigeria. Dove Education Publication.

11. Adepoju AO and Obayelu OA (2013) Livelihood diversification and welfare of rural household in Ondo State, Nigeria. J Dev Agric Econ 5(2): 482-489.

12. Nhemachena C (2009) Agriculture and future climate dynamics in Africa: Impacts and adaptation option. PhD thesis presented to Department of Agricultural Economics, Extension and Rural Development, University of Pretoria, pp. 150.

13. Deressa TR, C Hassan, TA Ringler and M Yusuf (2008) Analysis of the determinants of farmers' choice of adaptation methods and perceptions of climate change in the Nile Basin of Ethiopia. IFPRI: Washington DC, USA.

14. Asfaw A and A Assefa (2004) The role of education on the adoption of chemical fertilizer under different socio-economic environment in Ethiopia. Agric Econs 30(3): 215-228.

15. Nhemachena C and R Hassan (2008) Determinants of African farmers strategies for adapting to climate change: Multinomial choice analysis. Afr J Agric Resource Econs 2(1): 83-104.

16. Gbetibouo G (2008), Understanding farmers' perceptions and adaptations to climate change and variability: The case of the Limpopo Basin, South Africa, IFPRI: Washington DC, USA.

17. Tesfaye Z (2004) Adoption of inorganic fertilizer on maize in Amhara, Oromia and Southern regions, EARO, Addis Ababa, Ethiopia.

18. Maddison D (2006) The perception of adaptation to climate change in Africa. University of Pretoria: Johannesburg. PMCID: PMC: 1698947.

19. Ikeme J (2009) Assessing the future of Nigeria's economy: Ignored threats from the global climate change debate.

20. National Population Commission (NPC) (2006) Provisional Population Census Report, Abuja.

21. Sayne A (2011) Climate change adaptation and conflict in Nigeria. Washington DC. (A Special Report 274), United States Institute of Peace.

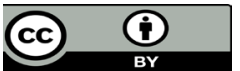

This work is licensed under Creative Commons Attribution 4.0 License

To Submit Your Article Click Here: Submit Article

DOI: $10.32474 /$ CIACR.2018.05.000213

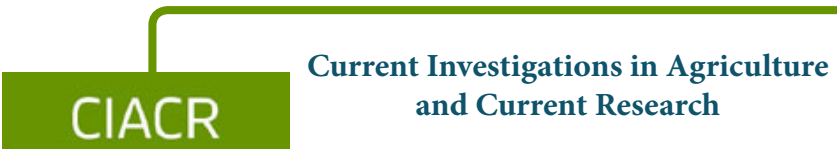

Assets of Publishing with us

- Global archiving of articles

- Immediate, unrestricted online access

- Rigorous Peer Review Process

- Authors Retain Copyrights

- Unique DOI for all articles 